\title{
Role of nitrogen versus phosphorus availability on the effect of UV radiation on bacterioplankton and their recovery from previous UV stress
}

\author{
Clemens Pausz, Gerhard J. Herndl* \\ Department of Biological Oceanography, Royal Netherlands Institute for Sea Research (Royal NIOZ), PO Box 59, \\ 1790 AB Den Burg, The Netherlands
}

\begin{abstract}
The influence of nitrogen (N) versus phosphorus (P) availability on the sensitivity of marine bacterioplankton to solar radiation and on their recovery from UV stress was assessed in laboratory experiments under high versus low substrate concentrations. Bacterioplankton were exposed to artificial solar radiation closely resembling natural radiation levels for $4 \mathrm{~h}$ and aliquots were subsequently exposed to different radiation ranges for $3 \mathrm{~h}$. Bacterial activity was significantly reduced after exposure to solar radiation, as compared to the activity measured prior to the exposure, only in P-deplete conditions under both, high, and low substrate conditions. Exposure of the bacterioplankton to different radiation ranges following exposure to the full range of solar radiation revealed that nucleotide excision repair is probably more important than the photoenzymatic DNA repair mechanism. Recovery from previous UV stress was similar under N- and P-deplete bacterial growth at high substrate conditions. Under low substrate conditions, however, the recovery efficiency was significantly lower under P- than under N-deplete conditions. Thus, we conclude that to a large extent, $\mathrm{P}$ availability determines the sensitivity of bacterioplankton to UV radiation and the recovery efficiency from previous UV stress in oligotrophic surface waters.
\end{abstract}

KEY WORDS: UV radiation · Bacterioplankton $\cdot$ Substrate availability $\cdot$ Nitrogen $\cdot$ Phosphorus

\section{INTRODUCTION}

Ultraviolet-B (UV-B, 280 to $320 \mathrm{~nm}$ ) radiation penetrating into the water column influences the carbon and energy flux in the euphotic layer of the oceans and therefore has impact on the oceanic biogeochemical cycles (Moran \& Zepp 1997). In oligotrophic oceanic waters, the $10 \%$ level of surface solar radiation of the $340 \mathrm{~nm}$ wavelength is at about 30 to $40 \mathrm{~m}$ depth and that of $380 \mathrm{~nm}$ at 60 to $70 \mathrm{~m}$ depth (Obernosterer et al. 2001). Thus, about half of the photic zone is influenced by UV radiation (Obernosterer et al. 2001).

UV radiation affects marine microorganisms both directly and indirectly. Indirectly by UV-induced pho-

*Corresponding author. E-mail: herndl@nioz.nl tolysis of dissolved organic matter (DOM) resulting in a suite of photochemically formed organic and inorganic compounds (Kieber et al. 1990, Scully et al. 1996, Moran \& Zepp 1997). This cleavage of DOM might result in enhanced bioavailability of DOC to bacterioplankton (Lindell et al. 1995, Herndl et al. 1997) but also in growth inhibition due to the formation of free radicals (Palenik et al. 1991, Helz et al. 1994). Recently, it has been shown that photolysis of labile DOM renders it less bioavailable for bacteria (Benner \& Biddanda 1998, Tranvik \& Kokalj 1998, Pausz \& Herndl 1999, Obernosterer et al. 1999, 2001).

One of the direct, primary targets of UV radiation in microorganisms is DNA. The major forms of DNA damage induced by low wavelength solar radiation are cyclobutane dimers and pyrimidine (6-4) pyrimidone photoproducts (Karentz et al. 1991, Buma et al. 1995). 
In contrast to eukaryotic microorganisms and cyanobacteria, heterotrophic bacteria do not produce UV-absorbing pigments to shield off high energy UV radiation (Garcia-Pichel \& Castenholz 1993). Microorganisms have developed several mechanisms to repair DNA lesions, which are either induced under solar radiation in the presence of UV-A (320 to $400 \mathrm{~nm}$ ) and photosynthetic active radiation (PAR; 400 to $700 \mathrm{~nm}$ ), or induced in the dark (Friedberg 1985). These repair mechanisms are common to all bacteria (Arrage et al. 1993). The photoenzymatic repair (PER) is a light-dependent process where the photolyase absorbs photons from the higher UV-A and lower PAR range (360 to $430 \mathrm{~nm}$ ) to repair the DNA damage (Friedberg 1985, Karentz 1994, Chen et al. 1995). The induction of photolyase, therefore, does not require energy in the form of ATP, whereas the other important DNA repair mechanism, the nucleotide excision repair (NER), requires ATP (Friedberg 1985).

In a study performed in the coastal northern Adriatic Sea, it has been reported that the recovery rate of bacterioplankton from previous UV stress is higher in the presence of UV-A and PAR than in the dark (Kaiser \& Herndl 1997). This indicates that PER of DNA damage might be, at least under certain conditions, more important than NER. In a recent paper, Arrieta et al. (2000) showed that bacterial strains exhibit considerable interspecific variability in their sensitivity to UV radiation and that they use efficiently either PER or NER, but not both.

The aim of this study was to determine the influence of the availability of nitrogen $(\mathrm{N})$ and phosphorus $(\mathrm{P})$ on the impact of solar radiation including $\mathrm{UV}$ on marine bacterioplankton and on their recovery from previous UV stress. The rationale behind this is that $\mathrm{P}$ is a major element of the DNA and therefore essential for cell division while $\mathrm{N}$ is primarily used for the synthesis of proteins and therefore, biomass. Thus, the availability of $\mathrm{P}$ versus $\mathrm{N}$ should have different effects on the response of bacterioplankton to UV stress, and possibly on the recovery from it. As an integrative parameter to assess bacterial activity, we chose leucine incorporation into bacterial macromolecules rather than measuring the dynamics of DNA damage.

\section{MATERIALS AND METHODS}

To evaluate the response of marine bacterioplankton to exposure to solar radiation under $\mathrm{N}$ - versus $\mathrm{P}$ deplete conditions and the impact of $\mathrm{N}$ versus $\mathrm{P}$ availability on the recovery from previous UV stress, 4 laboratory experiments were performed with freshly collected bacterioplankton communities incubated at high and low substrate concentrations and exposed to artificial solar radiation. The 4 experiments with high and low substrate concentrations were performed between 22 to 26 January and 4 to 9 February 1999, respectively.

Experimental setup. Generally, dilution cultures with bacterioplankton communities inoculated in artificial seawater amended with nutrients were used in the experiments. Seawater was collected in acid-rinsed carboys at high tide from the Netherlands Institute for Sea Research's (NIOZ) pier located at the southern entrance to the Dutch Wadden Sea (Marsdiep, coastal North Sea). This water was filtered through $0.8 \mu \mathrm{m}$ polycarbonate filters (Millipore) to remove most of the non-bacterial particles. From the $0.8 \mu \mathrm{m}$ filtrate, $200 \mathrm{ml}$ were inoculated into $1.8 \mathrm{l}$ of artificial seawater amended with glucose, $\mathrm{NH}_{4}{ }^{+}, \mathrm{PO}_{4}{ }^{3-}$ and a mixture of amino acids at different concentrations to simulate high- and low-substrate conditions (Table 1). Natural bacterioplankton assemblages were inoculated within 0.5 to $1.5 \mathrm{~h}$ after sampling. The dilution cultures were held at 17 to $18^{\circ} \mathrm{C}$ in the dark for $24 \mathrm{~h}$. Subsequently, the dilution cultures were split into aliquots of $1 \mathrm{l}$ and enriched with either $\mathrm{PO}_{4}{ }^{3-}$ or $\mathrm{NH}_{4}{ }^{+}$to create an imbalance in $\mathrm{N}$ - or P-availability (as compared to the elemental composition of bacteria [C:N:P $=45: 9: 1$, Goldman et al. 1987]) under high- and low-substrate conditions (Table 1). After $12 \mathrm{~h}, 200 \mathrm{ml}$ of the $\mathrm{N}$ - and Plimited cultures were filled into combusted quartz tubes and exposed to artificial solar radiation for $4 \mathrm{~h}$ (Fig. 1). Immediately thereafter, the cultures were transferred to various radiation ranges for $3 \mathrm{~h}$ to evaluate the potential of the bacteria to recover from the previous UV stress under different nutrient conditions (Fig. 1). Immediately before and after the exposure to the full range of artificial solar radiation, bacterial

Table 1. Summary of nutrient conditions during the initial phase of the dilution cultures in artificial seawater lasting for $24 \mathrm{~h}$ and after $\mathrm{N}$ - or P-enrichment for the subsequent exposure to artificial solar radiation. Nutrient concentrations are given in $\mu \mathrm{M}$, the concentration of added amino acid (AA) mixture in $\mu \mathrm{M}$ N. Glu-C: glucose-C

\begin{tabular}{|c|c|c|c|c|c|c|c|}
\hline \multirow[t]{2}{*}{ Treatment } & \multicolumn{4}{|c|}{ Initial nutrient regime (in $\mu \mathrm{M}$ ) } & \multicolumn{2}{|c|}{ Added nutrients (in $\mu \mathrm{M}$ ) } & \multirow{2}{*}{$\begin{array}{l}\text { Number of } \\
\text { experiment }\end{array}$} \\
\hline & Glu-C & $\mathrm{NH}_{4}^{+}$ & $\mathrm{PO}_{4}{ }^{3-}$ & $\mathrm{AA}$ & $\mathrm{NH}_{4}{ }^{+}$or & $\mathrm{PO}_{4}^{3-}$ & \\
\hline High-nutrient regime & 100 & 10 & 1 & 0.4 & 40 & 4 & 4 \\
\hline Low-nutrient regime & 20 & 2 & 0.2 & 0.4 & 8 & 0.8 & 4 \\
\hline
\end{tabular}






Fig. 1. Experimental setup to test the role of different substrate levels and N:P ratios on the sensitivity of bacterioplankton to solar radiation and their recovery efficiency from previous UV-B stress under different radiation conditions. BP: bacterial production measurements at the end of the different stages of the incubation; PAR: photosynthetic active radiation

(400 to $700 \mathrm{~nm}$ ). For details see 'Materials and methods'

activity was measured via leucine incorporation as described below.

To evaluate the role of different wavelength ranges on the recovery efficiency, 3 different radiation regimens were established following the exposure to the full spectrum of solar radiation: UV-A + PAR excluding UV-B by wrapping the quartz tubes in Mylar-D foil (Dupont); PAR alone by wrapping tubes in vinyl chloride foil (CI Kasei); and a dark control (tube wrapped in aluminum foil). After $3 \mathrm{~h}$ of exposure to the different radiation regimens, bacterial activity was re-assessed.

Radiation conditions. Artificial solar radiation was provided by 3 different types of light sources. Two HQIT Powerstar (Osram) lamps provided PAR, 2 TL 100W/ 10R fluorescent light tubes (Philips) were used to provide UV-A, and 3 UVA-340 fluorescent light tubes (Q-Panel) provided UV-A and UV-B. The solar simulator was adjusted to 30 to $60 \%$ of the local maximum radiation intensity in late spring measured on a cloudless day (Table 2). To maintain constant water-temperature conditions during the exposure to the different regimens of artificial solar radiation $\left(17\right.$ to $\left.18^{\circ} \mathrm{C}\right)$, the treatments were kept in a flow-through water bath connected to a temperature control unit (LAUDA RCS/RC-6).

Bacterial production. Bacterial production was determined via the incorporation of L- $\left[{ }^{14} \mathrm{C}\right]$ leucine (specific activity [SA] $55.0 \mathrm{mCi} \mathrm{mmol}^{-1}$, Amersham) into bacterial macromolecules (Simon \& Azam 1989). Duplicate $5 \mathrm{ml}$ samples and 1 formaldehyde-fixed blank (2\% final concentration) were spiked with $20 \mathrm{nM}$ leucine (final concentration) and incubated in the dark at $17^{\circ} \mathrm{C}$ for 20 to $30 \mathrm{~min}$. Thereafter, the samples were fixed by adding $0.5 \mathrm{ml}$ of concentrated formalin. Samples were filtered onto $0.2 \mu \mathrm{m}$ cellulose-nitrate filters (Millipore) and the filters rinsed twice with $5 \mathrm{ml}$ of $5 \%$ ice-cold trichloroacetic acid. The filters were then placed in scintillation vials and a scintillation cocktail of $1 \mathrm{ml}$ ethylacetate and $8 \mathrm{ml}$ liquid (Ultima Gold, Packard) was added. After $12 \mathrm{~h}$, the radioactivity was determined with a LKB-Wallac 1211 RackBeta liquid scintillation counter. Bacterial production was calculated using the conversion factor of $3090.84 \mathrm{~g}$ bacterial C produced per mol leucine incorporated (Simon \& Azam 1989).

Statistical analyses. The results from the 4 experiments were pooled for statistical analyses. Unless stated otherwise, statistical analyses were performed using the Wilcoxon matched-pair test and the nonparametric Friedman test (SPSS Systat 7.0).

Table 2. Comparison between the radiation intensities used in the experiments with artificial solar radiation and natural solar radiation, measured under cloudless conditions at the Netherlands Institute for Sea Research's (NIOZ) pier, on 26 June 1999 at 12:00 and $16.00 \mathrm{~h}$. Radiation measurements were performed with a Biospherical PUV-510 radiometer at the indicated wavelengths; PAR: photosynthetic active radia-

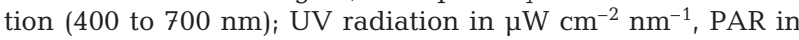
$\mu \mathrm{E} \mathrm{cm}^{-2} \mathrm{~s}^{-1}$

\begin{tabular}{|c|c|c|c|c|c|}
\hline & $\begin{array}{l}305 \\
\mathrm{~nm}\end{array}$ & $\begin{array}{l}320 \\
\mathrm{~nm}\end{array}$ & $\begin{array}{l}340 \\
\mathrm{~nm}\end{array}$ & $\begin{array}{l}380 \\
\mathrm{~nm}\end{array}$ & PAR \\
\hline $12: 00 \mathrm{~h}$ & 2.664 & 28.69 & 50.87 & 65.47 & 0.18 \\
\hline $16: 00 \mathrm{~h}$ & 0.497 & 11.53 & 23.92 & 31.68 & 0.09 \\
\hline Artificial solar radiation & 1.77 & 11.7 & 20.9 & 21.9 & 0.08 \\
\hline
\end{tabular}




\section{RESULTS}

\section{Bacterioplankton response to full solar- radiation exposure}

The response of bacterial communities held at high versus low substrate regimes and exposed to the full range of artificial solar radiation is shown in Fig. 2. The initial bacterial production (i.e. before exposure to artificial solar radiation) in the dilution cultures with high substrate levels was $19.6 \pm 11.9 \mu \mathrm{g} \mathrm{C}^{-1} \mathrm{~h}^{-1}(\mathrm{n}=4)$ for P-deplete and $11.6 \pm 6.1 \mu \mathrm{g} \mathrm{C}^{-1} \mathrm{~h}^{-1}(\mathrm{n}=4)$ for $\mathrm{N}$ deplete cultures. Exposure to artificial solar radiation at high substrate levels for $4 \mathrm{~h}$ resulted in a decline in bacterial activity in the P-deplete cultures by $46 \pm 24 \%$ ( $\mathrm{n}=4$; Fig. 2a). Bacterial activity in the N-deplete dilution cultures continued to increase (by $42 \pm 21 \%$; $=4$ ) as compared to the initial bacterial activity prior to exposure (Fig. 2a).


Fig. 2. Bacterial production prior to $\left(t_{0}\right)$ and after $\left(t_{1}\right)$ the exposure to the full range of artificial solar radiation, and after the subsequent recovery treatment $\left(t_{2}\right)$ when UV-B was excluded under P- versus N-deplete conditions. Bacterial production is expressed as \% production at $t_{0}$. (a) High- and (b) lowsubstrate levels. For nutrient concentrations see Table 1. Symbols represent mean $\pm \mathrm{SD}$ of 4 experiments
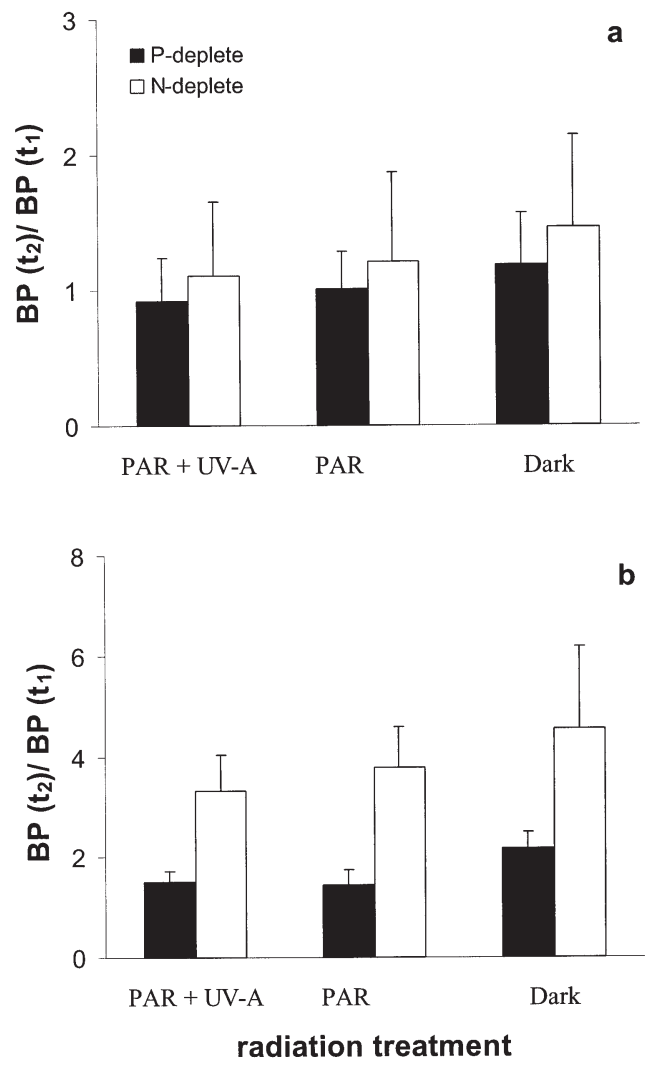

Fig. 3. Ratio between bacterial production (BP) measured after the recovery treatments under different radiation ranges (PAR + UV-A, PAR, dark) at $\left(t_{2}\right)$ and BP after exposure to the full range of solar radiation $\left(t_{1}\right)$ at (a) high- and (b) lowsubstrate levels under $\mathrm{P}$ - versus $\mathrm{N}$-deplete conditions. Bars represent mean $+\mathrm{SD}$ of 4 experiments

Bacterial cultures held at low substrate levels exhibited an initial production (prior to exposure to artificial solar radiation) of $3.7 \pm 0.4 \mu \mathrm{g} \mathrm{C}^{-1} \mathrm{~h}^{-1}(\mathrm{n}=4)$ under $\mathrm{P}$ deplete and $3.3 \pm 1.2 \mu \mathrm{g} \mathrm{C}^{-1} \mathrm{~h}^{-1}(\mathrm{n}=4)$ under $\mathrm{N}$ deplete conditions. After the $4 \mathrm{~h}$ exposure to the full range of artificial solar radiation, bacterial activity declined by $46 \pm 16 \%(\mathrm{n}=4)$ under P-deplete conditions, whereas bacterial production under $\mathrm{N}$-deplete conditions increased slightly to $105 \pm 54 \%$ (n = 4; Fig. 2b). As for the exposure to the high-substrate levels, also at low-substrate levels bacterial production was significantly reduced under P- as compared to Ndeplete conditions (Wilcoxon, $\mathrm{p}=0.068$; for each $\mathrm{n}=4$ ).

\section{Recovery of the bacterioplankton community from previous UV stress}

At high substrate levels, bacterioplankton previously exposed to the full range of solar radiation for $4 \mathrm{~h}$, and subsequently exposed to different ranges of solar radiation for an additional $3 \mathrm{~h}$ exhibited significantly 
higher recovery efficiency under dark conditions in both $\mathrm{N}$ - and P-deplete cultures (Friedman, $\mathrm{p}=0.046$ for both treatments; $\mathrm{n}=4$ ) than under PAR + UV-A and PAR conditions (Fig. 2a). There was no significant difference between the recovery under PAR + UV-A and PAR radiation in either the $\mathrm{P}$ - or the $\mathrm{N}$-deplete cultures.

At low substrate levels, bacterioplankton generally showed a higher recovery efficiency under $\mathrm{N}$ - than under $\mathrm{P}$-deplete conditions in all 3 radiation treatments: UV-A + PAR, PAR, dark (Friedman, $\mathrm{p}=0.046 ; \mathrm{n}=4$; Fig. 2b). As for the high substrate levels, bacterioplankton held in the dark following exposure to the full range of solar radiation exhibited a higher recovery than either the UV-A + PAR or the PAR treatment. Fig. 3 shows the ratio between the bacterial production measured at the end of the recovery period (for the 3 different radiation regimens) and the production after exposure to the full range of solar radiation. While there was no significant difference at the high substrate level between P- and N-deplete conditions (Fig. 3a), at low substrate levels significantly higher recovery efficiencies were obtained for $\mathrm{N}$ - than for P-deplete bacterioplankton (Friedman, $\mathrm{p}=0.046$; Fig. 3b).

\section{DISCUSSION}

To ensure comparable conditions over the course of the experiments, we used artificial solar radiation and artificial seawater amended with substrates at specific concentrations.

Artificial solar radiation was provided by a lamp configuration which closely resembles natural solar radiation up to a wavelength of about $700 \mathrm{~nm}$. The intensity of the radiation was chosen to be 30 to $60 \%$ (depending on the wavelength considered) of the maximum radiation, measured on 2 cloudless days in late spring, and the exposure time was limited to $4 \mathrm{~h}$. Thus, the radiation dose provided in these experiments was close to natural conditions in the near-surface layers of the North Sea (Table 2).

Artificial seawater amended with glucose and major inorganic nutrients was used to ensure that the same amount of nutrients was potentially available in all the experiments. Since the chemical composition of natural DOM is rather complex and its characterization on a molecular level is not possible at present, it also remains unknown at which rate all the different DOM compounds are incorporated into bacterioplankton cells. Moreover, the composition of the DOM changes considerably, even over short-time scales (Burney et al. 1982, Herndl \& Malacic 1987, Suttle et al. 1991). Despite the lack of detailed knowledge on the chemical composition of marine DOM, complex chemical alterations of the DOM pool take place upon its exposure to solar radiation, particularly to UV radiation. On the one hand, it has been shown that a suite of compounds produced from parent DOM is readily bioavailable, making the DOM pool generally more accessible for bacterioplankton utilization (Moran \& Zepp 1997, Tranvik \& Kokalj 1998, Obernosterer et al. 1999). However, on the other hand, originally labile DOM might be photochemically altered to become more refractory (Benner \& Biddanda 1998, Obernosterer et al. 1999, 2001, Pausz \& Herndl 1999). It is impossible to account for all these complex photochemical alterations of natural DOM which might have contrasting effects on bacterioplankton. Thus, we used artificial seawater amended with nutrients which do not absorb solar radiation efficiently. We therefore assume that in the experimental approach used in this study, photochemical processes on the substrate pool are not biasing our results.

The substrate concentrations used in this study were meant to allow investigation of the bacterioplankton response under both high and low concentrations of bioavailable substrates where either $\mathrm{N}$ or $\mathrm{P}$ availability is controlling bacterial growth. The N:P ratios of the added nutrients were chosen on the basis of the elemental composition of bacterioplankton, with a ratio of $\mathrm{C}: \mathrm{N}: \mathrm{P}=45: 9: 1$ (Goldman et al. 1987).

In previous studies on the impact of solar radiation on bacterioplankton, it has been found that exposure to surface-level solar radiation leads to significantly reduced bacterial activity (Herndl et al. 1993, Jeffrey et al. 1996, Joux et al. 1999, Arrieta et al. 2000). In our study, a significant reduction in bacterioplankton activity upon exposure to lower levels of solar radiation than used in the previous studies was only detectable under P-deplete conditions (Fig. 2). Thus, upon direct exposure, bacterioplankton are more sensitive to solar radiation under $\mathrm{P}$ - than under $\mathrm{N}$-deplete conditions.

In the water column, solar radiation is attenuated depending on its wavelengths, leading to a characteristic composition of light depending on depth (Jerlov 1976, Kirk 1994). Mixing of the upper layers of the water column is frequently limited due to diurnal stratification of these layers caused by solar heating (Obernosterer et al. 2001). If mixing of the upper layers of the water column takes place, because of either strong wind-induced mixing or surface cooling of the uppermost layers, bacterioplankton are mixed into deeper layers where UV-B is already largely attenuated while UV-A and PAR are still present. Under such conditions, the PER mechanism can be effective as long as there is sufficient short-wavelength PAR present. To evaluate the importance of the different radiation regimens, at different substrate concentrations, on the recovery efficiency of bacterioplankton from previous UV stress, 
we shielded off different parts of the solar radiation spectrum from the quartz tubes in which the bacterioplankton were incubated.

At high substrate levels, no significant difference in the recovery efficiency of bacterioplankton between $\mathrm{N}$ - and P-deplete conditions was detectable (Fig. 3a). At low substrate levels, however, P-deplete bacteria recovered from previous UV stress at significantly lower rates than $\mathrm{N}$-deplete bacteria (Fig. 3b). Differences in the radiation regimens were generally less important for the recovery efficiency than the nature of the growth limiting element at low substrate levels (Fig. 3b). This indicates that light-independent repair mechanisms, among them most likely NER, were more important in this study than PER. In a previous study performed with bacterioplankton of the northeastern Adriatic Sea, Kaiser \& Herndl (1997) found that bacterial recovery from previous UV stress is higher under UV-A + PAR exposure than under dark conditions. Hence, it was concluded from these experiments that PER is more important than NER in repairing DNA damage caused by UV radiation (Kaiser \& Herndl 1997). However, as has been shown recently on bacterial strains isolated from different parts of the world's oceans, there are remarkable strain-specific differences in the efficiency of PER and NER to repair DNA damage (Arrieta et al. 2000). In the present study, we expected PER to dominate under P-deplete conditions since it does not require additional $\mathrm{P}$, whereas in $\mathrm{N}$-deplete cultures the less error-prone NER was expected to prevail. Such a pattern in DNA repair, however, could only have been obtained in our experimental setting if bacterial species were capable of switching between the different modes of DNA repair. As shown by Arrieta et al. (2000), bacterial strains use efficiently either PER or NER, but not both. Thus, bacterial strains have limited capabilities to switch modes, resulting in a rather uniform pattern of bacterial recovery from UV stress independent of the radiation regimens in our experiments.

Species-specific differences in the sensitivity to and the recovery from UV stress might lead to shifts in the community composition in surface waters. This has been addressed in a previous study where bacterioplankton, collected from the same sampling site as used in this study, were exposed to different radiation regimens, and the composition of the bacterioplankton community was subsequently documented by denaturing-gradient gel electrophoresis (Winter et al. 2001). Only subtle changes in the bacterioplankton community were found upon exposure to solar radiation as compared to communities held in the dark (Winter et al. 2001). Even the most UV-sensitive bacterial species in these exposure experiments was present in the surface waters of the North Sea throughout the summer, indicating efficient repair of UV-induced DNA damage under natural conditions.

Regardless of the repair mechanism used by bacterioplankton species, we have shown that the sensitivity of bacterioplankton to UV radiation and the recovery from previous UV stress depends to a large extent on the availability of P. In the surface waters of the global ocean, however, $\mathrm{P}$ is frequently limiting bacterioplankton activity (Rivkin \& Anderson 1997, Kuipers et al. 2000). Thus, under these conditions, bacterioplankton appear to be more susceptible to UV than under Ndeplete conditions. Our results indicate, therefore, that the availability of $\mathrm{P}$ for bacterioplankton growth determines the direct impact of UV radiation on bacterioplankton in the oceanic near-surface layers.

Acknowledgements. Financial support was provided by a TMR grant (project \# ENV4-CT97-5077) and the COMET project of the ELOISE cluster (project \# EVK1-1999-00175) of the Commission of the European Union. This is Royal NIOZ contribution \# 3705. This work is in partial fulfillment of the requirements for a $\mathrm{PhD}$ degree from the University of Vienna, Austria, by C.P.

\section{LITERATURE CITED}

Arrage AA, Phelps TJ, Benoit RE, White DC (1993) Survival of subsurface microorganisms exposed to UV radiation and hydrogen peroxide. Appl Environ Microbiol 59:3545-3550

Arrieta JM, Weinbauer MG, Herndl GJ (2000) Interspecific differences in sensitivity to UV radiation and subsequent recovery in selected isolates of marine bacteria. Appl Environ Microbiol 66:1468-1473

Benner R, Biddanda B (1998) Photochemical transformation of surface and deep marine dissolved organic matter: effects on bacterial growth. Limnol Oceanogr 43:1373-1378

Buma AGJ, Hannen EJV, Roza L, Veldhuis MJW, Gieskes WWC (1995) Monitoring ultraviolet-B induced DNA damage in individual diatom cells by immunofluorescent thymine dimer detection. J Phycol 31:314-321

Burney CM, Davis PG, Johnson KM, Sieburth JM (1982) Diel relationships of microbial trophic groups and in situ dissolved carbohydrate dynamics in the Caribbean Sea. Mar Biol 67:311-322

Chen JJ, Mitchell DL, Britt AB (1995) A light-dependent pathway for the elimination of UV-induced pyrimidine (6-4) pyrimidinone photoproducts in Arabidopsis. Plant Cell 6: 1311-1317

Friedberg EC (1985) DNA repair. WH Freeman, New York

Garcia-Pichel F, Castenholz RW (1993) Occurrence of UVabsorbing, mycosporine-like compounds among cyanobacterial isolates and an estimate of their screening capacity. Appl Environ Microbiol 59:163-169

Goldman JC, Caron DA, Dennett MR (1987) Regulation of gross growth efficiency and ammonium regeneration in bacteria by substrate $\mathrm{C}: \mathrm{N}$ ratio. Limnol Oceanogr 32: 1239-1252

Helz GR, Zepp RG, Crosby DG (1994) Aquatic and surface photochemistry. Lewis Publishers, Boca Raton

Herndl GJ, Malacic V (1987) Impact of the pycnocline layer on bacterioplankton: diel and spatial variations in micro- 
bial parameters in the stratified water column of the Gulf of Trieste (Northern Adriatic Sea). Mar Ecol Prog Ser 38: 295-303

Herndl GJ, Müller-Niklas G, Frick J (1993) Major role of ultraviolet-B in controlling bacterioplankton growth in the surface layer of the ocean. Nature 361:717-719

Herndl GJ, Brugger A, Hager S, Kaiser E, Obernosterer I, Reitner B, Slezak D (1997) Role of ultraviolet-B radiation on bacterioplankton and the availability of dissolved organic matter. Plant Ecol 128:42-51

Jeffrey WH, Pledger RJ, Aas P, Hager S, Coffin RB, Haven RV, Mitchell DL (1996) Diel and depth profiles of DNA photodamage in bacterioplankton exposed to ambient solar ultraviolet radiation. Mar Ecol Prog Ser 137:283-291

Jerlov NG (1976) Marine optics. Elsevier Science Publishers, Amsterdam

Joux F, Jeffrey WH, Lebaron P, Mitchell DL (1999) Marine bacterial isolates display diverse responses to UV-B radiation. Appl Environ Microbiol 65:3820-3827

Kaiser E, Herndl GJ (1997) Rapid recovery of marine bacterioplankton activity after inhibition by UV radiation in coastal waters. Appl Environ Microbiol 63:4026-4031

Karentz D (1994) Ultraviolet tolerance mechanisms in Antarctic marine organisms. In: Weiler CS, Penhale PA (eds) Ultraviolet radiation in Antarctica: measurements and biological effects. American Geophysical Union, Washington, DC, p 93-110

Karentz D, Cleaver JE, Mitchell DL (1991) Cell survival characteristics and molecular responses of Antarctic phytoplankton to ultraviolet-B radiation. J Phycol 27:326-341

Kieber RJ, Zhou X, Mopper K (1990) Formation of carbonyl compounds from UV-induced photodegradation of humic substances in natural waters: fate of riverine carbon in the sea. Limnol Oceanogr 35:1503-1515

Kirk JTO (1994) Optics of UV-B radiation in natural waters. Arch Hydrobiol Beiheft 43:1-16

Kuipers B, Noort GJv, Vosjan JH, Herndl GJ (2000) Diel periodicity of bacterioplankton in the euphotic zone of the subtropical Atlantic Ocean. Mar Ecol Prog Ser 201:13-25

Editorial responsibility: John Dolan,

Villefranche-sur-Mer, France
Lindell MJ, Granéli W, Tranvik LJ (1995) Enhanced bacterial growth in response to photochemical transformation of dissolved organic matter. Limnol Oceanogr 40:195-199

Moran MA, Zepp RG (1997) Role of photoreactions in the formation of biologically labile compounds from dissolved organic matter. Limnol Oceanogr 42:1307-1316

Obernosterer I, Reitner B, Herndl GJ (1999) Contrasting effects of solar radiation on dissolved organic matter and its bioavailability to marine bacterioplankton. Limnol Oceanogr 44:1645-1654

Obernosterer I, Sempéré R, Herndl GJ (2001) Ultraviolet radiation induces a reversal of the bioavailability of DOM to marine bacterioplankton. Aquat Microb Ecol 24:61-68

Palenik B, Price NM, Morel FMM (1991) Potential effects of UV-B on the chemical environment of marine organisms: a review. Environ Pollut 70:117-130

Pausz C, Herndl GJ (1999) Role of ultraviolet radiation on phytoplankton extracellular release and its subsequent utilization by marine bacterioplankton. Aquat Microb Ecol 18:85-93

Rivkin RB, Anderson MA (1997) Inorganic nutrient limitation of oceanic bacterioplankton. Limnol Oceanogr 42:730-740

Scully NM, McQueen DJ, Lean DRS, Cooper WJ (1996) Hydrogen peroxide formation: the interaction of ultraviolet radiation and dissolved organic carbon in lake waters along a $43-75^{\circ} \mathrm{N}$ gradient. Limnol Oceanogr 41:540-548

Simon M, Azam F (1989) Protein content and protein synthesis rates of planktonic marine bacteria. Mar Ecol Prog Ser 51:201-213

Suttle CA, Chan AM, Fuhrman JA (1991) Dissolved free amino acids in the Sargasso Sea: uptake and respiration rates, turnover times, and concentration. Mar Ecol Prog Ser 70:189-199

Tranvik L, Kokalj S (1998) Decreased biodegradability of algal DOC due to interactive effects of UV radiation and humic matter. Aquat Microb Ecol 14:301-307

Winter C, Moeseneder MM, Herndl GJ (2001) Impact of UV radiation on bacterioplankton community composition. Appl Environ Microbiol 67:665-672

Submitted: April 5, 2002; Accepted: June 3, 2002

Proofs received from author(s): July 23, 2002 